\title{
MORTALITY FROM CORONARY ARTERY DISEASE AND "MYOCARDIAL DEGENERATION" IN THE REPUBLIC OF IRELAND
}

\author{
BY \\ ROY M. ACHESON AND E. H. THORNTON \\ From Trinity College, University of Dublin
}

Ryle and Russell (1949) published convincing evidence that the number of deaths due to coronary artery disease in England and Wales had increased dramatically between 1921 and 1939, and the Registrar General (1953b) has shown that this increase was maintained through the post-war years. Other workers, particularly Morris and his associates (Morris, 1951; Morris, Heady, and Barley, 1952; Morris, Heady, Raffle, Roberts, and Parks, 1953), have found that, besides causing premature death in certain sections of the community, coronary artery disease is an important cause of morbidity amongst men in their prime. Morris (1955) suggests that among contributory causes of the changing pattern of this disease are the altered way of life ("high development" he calls it) which followed the Industrial Revolution in "Western" countries.

The 26 counties which make up the Republic of Ireland* have, to a great extent, been spared the evil consequences of the Industrial Revolution. Dublin, the capital, has over 500,000 inhabitants, but this population is more concerned with commerce and the mechanics of government than with industry. Nowhere else in the state is a town or city to be found which has over 80,000 inhabitants, nor is there any industrial centre in the sense that Bradford, Bremen, or Pittsburgh are industrial. Moreover the modus vivendi of many rural communities in the Western counties (Donegal, Sligo, Mayo, Galway, Clare, and Kerry) has been little affected by the advent of such 20th century innovations as electricity and the internal combustion engine. Thus, it seemed that an analysis of deaths in the Republic, certified as due to coronary artery

*The constitution and official name of the state have changed more than once since it achieved its independence in 1922. Throughout the present paper we shall use this name regardless of the period to which we are referring. disease or "myocardial degeneration" over the past 30 years might be of some value.

Unfortunately, it has proved impossible to include statistics from Northern Ireland, because the Registrar General there has always combined deaths from coronary artery disease and myocardial degeneration under a single heading, and we have considered it desirable to treat these two groups separately.

\section{DATA}

The data are drawn from annual reports of the registration of births, marriages, and deaths in the Republic of Ireland from 1926-1957, prepared on behalf of the Registrar General. In these reports, certified deaths, analysed by sex and quinquennial age groups, are classified according to the Intermediate International List. Since 1926 this list has been revised three times, but is has proved possible to distinguish between myocardial degeneration and coronary artery disease in such a way as to obtain a reasonably coherent series for each over the whole period. Details of the International List numbers which have been adopted for this study are given in Table I (opposite).

In order to make certain comparisons between deaths in the Republic of Ireland and other countries, data have been taken from the Reports of the Registrar General for England and Wales (1928-1957) and for Scotland (1928-1957), and of the World Health Organisation (1956).

\section{RESUlts}

SeCular TRend.-The comparative mortality indices for males and females in respect of coronary artery disease and myocardial disease from 1926-1956 are shown in Fig. 1 (overleaf). Throughout the period, 
TABLE I

DESCRIPTION OF DISEASES CLASSIFIED AS CORONARY ARTERY DISEASE AND MYOCARDIAL DISEASE

\begin{tabular}{|c|c|c|c|c|}
\hline \multirow{2}{*}{ Date } & \multicolumn{2}{|r|}{ Coronary Group } & \multicolumn{2}{|c|}{ Myocardial Group } \\
\hline & $\begin{array}{l}\text { International } \\
\text { List No. }\end{array}$ & Definition & $\begin{array}{l}\text { International } \\
\text { List No. }\end{array}$ & Definition \\
\hline $\begin{array}{c}1926-30 \\
\text { (Third Revision) }\end{array}$ & 89 & Angina pectoris & $\begin{array}{l}90(b) \\
90(c) \\
91(b)\end{array}$ & $\begin{array}{l}\text { Fatty heart } \\
\text { Other and unstated forms of heart } \\
\text { disease } \\
\text { Arteriosclerosis }\end{array}$ \\
\hline $\begin{array}{c}1931-39 \\
\text { (Fourth Revision) }\end{array}$ & 94 & $\begin{array}{l}\text { Diseases of coronary arteries and } \\
\text { angina pectoris }\end{array}$ & $\begin{array}{l}93(a) \\
93(b) \\
93(c) \\
93(d)\end{array}$ & $\begin{array}{l}\text { Acute myocarditis } \\
\text { Fatty heart } \\
\text { Chronic myocarditis, myocardial } \\
\text { degeneration } \\
\text { Other and unspecified diseases of } \\
\text { the myocardium }\end{array}$ \\
\hline $\begin{array}{c}1940-49 \\
\text { (Fifth Revision) }\end{array}$ & 94 & $\begin{array}{l}\text { Diseases of coronary arteries and } \\
\text { angina pectoris }\end{array}$ & 93 & Diseases of the myocardium \\
\hline $\begin{array}{c}1950-56 \\
\text { (Sixth Revision) }\end{array}$ & $\begin{array}{l}420.0 \\
420.1 \\
420.2\end{array}$ & $\begin{array}{l}\text { Arteriosclerotic heart disease } \\
\text { Heart disease specified as involv- } \\
\text { ing coronary arteries } \\
\text { Angina pectoris without mention } \\
\text { of coronary arteries }\end{array}$ & $\begin{array}{l}422.0 \\
422.1 \\
422.2\end{array}$ & $\begin{array}{l}\text { Fatty degeneration of the heart } \\
\text { Myocardial degeneration with } \\
\text { arteriosclerosis } \\
\text { Other forms of myocardial de- } \\
\text { generation }\end{array}$ \\
\hline
\end{tabular}

the mortality due to coronary artery disease has increased for both sexes*; so much so that for every male or female death from this disease in 1926 there were over thirty deaths in 1956 . It will be noted, however, that for both sexes the increase was temporarily checked during the period 1940-1943, a time when death rates from the same cause were falling in England and Wales (Registrar General, 1953b).

The change in the death rates due to myocardial

*The slight downward turn in 1956 may be genuine or it may be explained by errors in estimating the age breakdown of the population for that year; for, although a Census of Population was taken in 1951, the considerable volume of emigration renders extrapolation extremely hazardous. The age analysis of the 1956 Census of Population has been halted in the interests of national economy. degeneration is not nearly so striking; the fall in both sexes between 1930 and 1931 was presumably due to a change in the International Classification (see Table I). From 1931 there is a slow rise which reaches a plateau during the war years and has been followed during the last decade by a slow fall.

AGE INCIDENCE.-The age groups of the population which bear the brunt of the increased death rate due to coronary artery disease are indicated in Table II. Here the average annual death rates for each of the three decades studied are given in quinquennial age groups, and the indices for the two subsequent decades are calculated taking the figures

TABLE II

AVERAGE ANNUAL DEATH RATES PER 100,000 FOR CORONARY ARTERY DISEASE IN THE REPUBLIC OF IRELAND, BY AGE GROUP, AND SEX

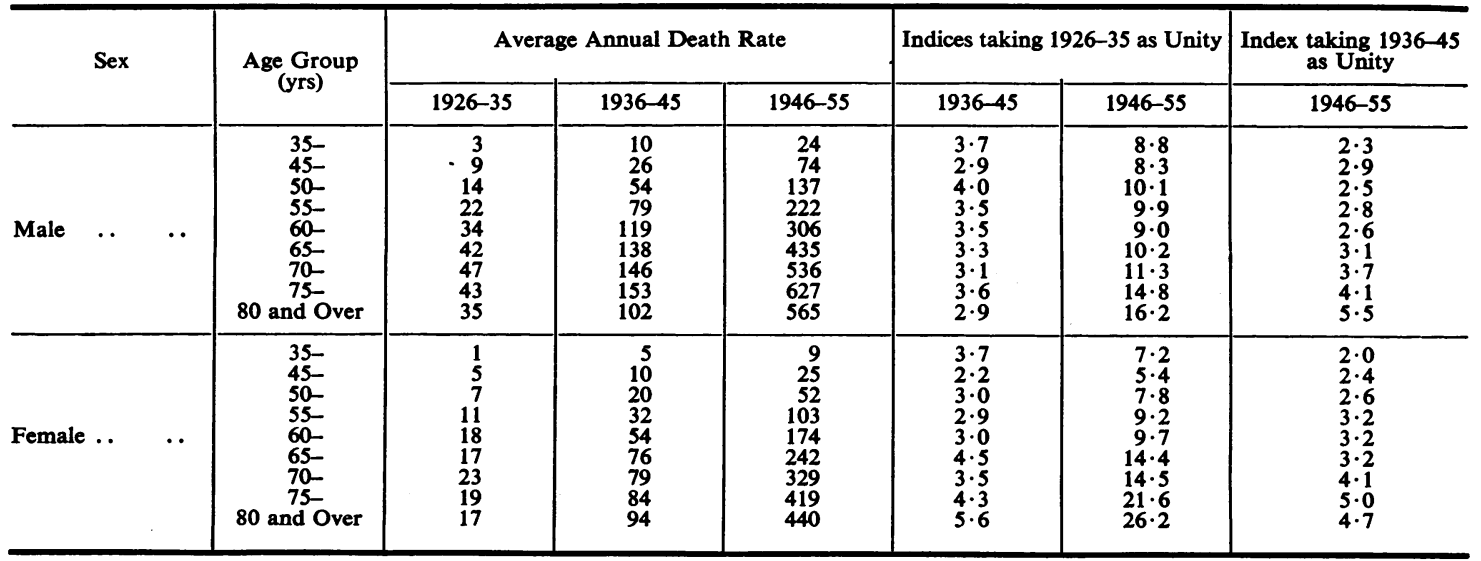




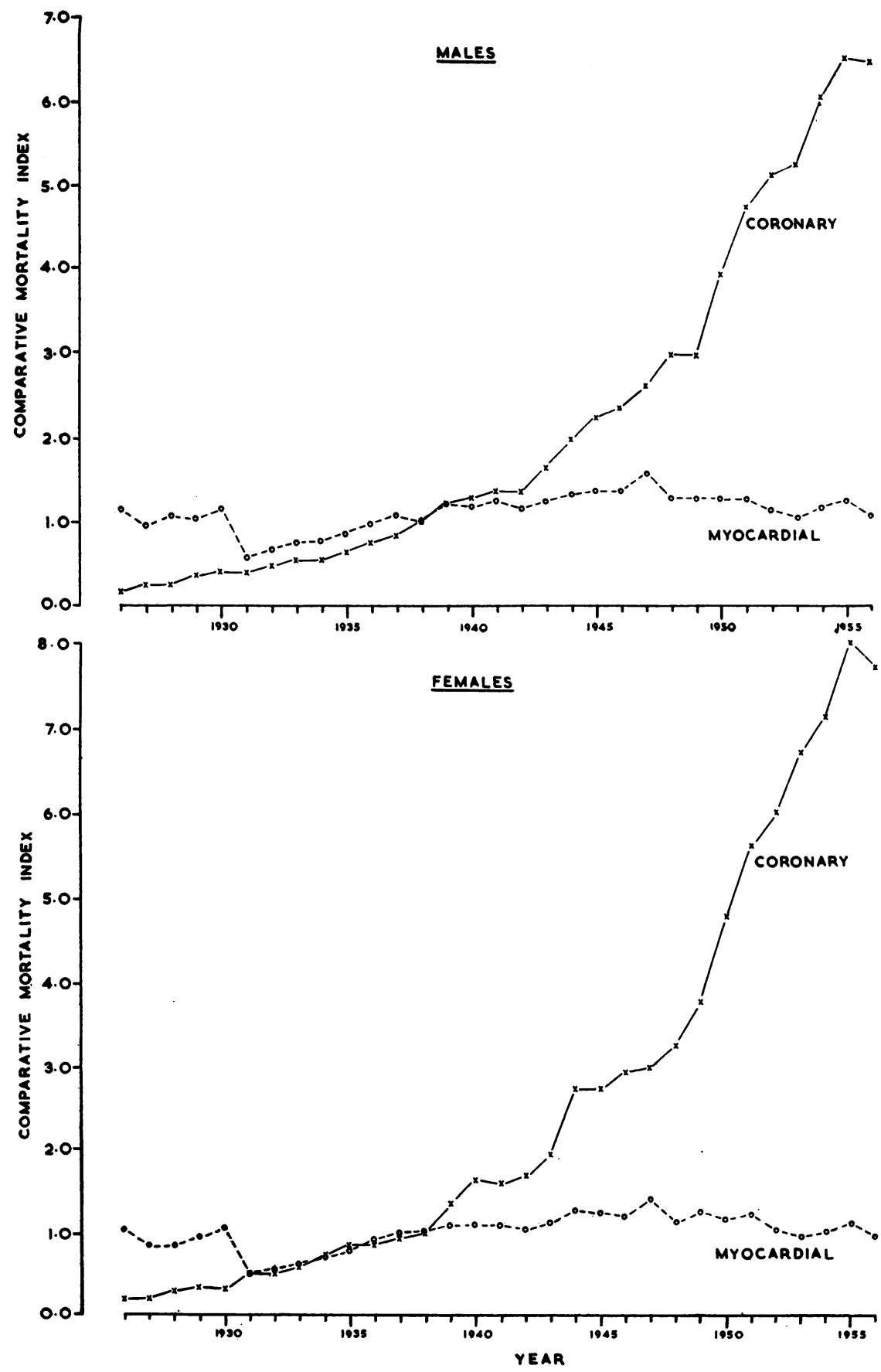

FIG. 1.- Comparative mortality indices for coronary artery disease and myocardial degeneration in the Republic of Ireland from 1926 to 1956 , by sex. 
for the period 1926-1935 as unity. The sharpest increase in male deaths during the decade 1936-1945 was experienced in middle age; during the following decade, however, the increases in all age groups between 35 and 64 were very similar the most pronounced rise being in men aged 65 years and over. This is also true when death rates for the decade 1936-1945 are taken as unity and the index calculated for 1946-1955.

The pattern of female deaths is a little different, for, during the decade 1936-1945 as compared with 1926-1935, sharp rises occur among those aged 65 and over, and during the decade 1946-1955 the gradient rises almost without interruption from $7 \cdot 2$ in the youngest group to 26.2 in the oldest. If the period 1946-1955 is compared with the preceding decade a similar pattern is manifest; in women who are probably still fertile, mortality is only doubled, whereas in those aged 70 and over the increase is between four- and five-fold.

SeX Differences.-Fig. 2, in which the comparative mortality indices are plotted on a ratio scale, shows that the rate of increase in women seems to be consistent with that in men throughout the 30 years under study. A further analysis of sex differences, taking age into account, is shown in Table III, where the ratios of male to female death rates for each of the three decades are compared. During the decade 1926-1935, the ratio is in the order of two male deaths for every female death for the entire age range. In the succeeding decades, however, the

TABLE III

SEX RATIO (M/F) FOR CORONARY ARTERY DISEASE MORTALITY IN IRELAND, BY AGE GROUP

\begin{tabular}{|c|c|c|c|}
\hline \multirow{2}{*}{$\underset{\text { (yrs) }}{\text { Age Group }}$} & \multicolumn{3}{|c|}{ Decade } \\
\hline & 1926-1935 & $1936-1945$ & 1946-1955 \\
\hline $\begin{array}{l}35- \\
45- \\
50- \\
55- \\
60- \\
65- \\
70- \\
75- \\
80 \text { and Over }\end{array}$ & $\begin{array}{l}2 \cdot 1 \\
2 \cdot 0 \\
2 \cdot 0 \\
2 \cdot 0 \\
1 \cdot 0 \\
2 \cdot 5 \\
2 \cdot 1 \\
2 \cdot 2 \\
2 \cdot 1\end{array}$ & $\begin{array}{l}2 \cdot 1 \\
2 \cdot 5 \\
2 \cdot 7 \\
2 \cdot 5 \\
2 \cdot 5 \\
1 \cdot 8 \\
1 \cdot 8 \\
1 \cdot 8 \\
1 \cdot 1\end{array}$ & $\begin{array}{l}2 \cdot 5 \\
3 \cdot 0 \\
2 \cdot 6 \\
2 \cdot 2 \\
1 \cdot 8 \\
1 \cdot 8 \\
1 \cdot 6 \\
1 \cdot 5 \\
1 \cdot 5\end{array}$ \\
\hline
\end{tabular}

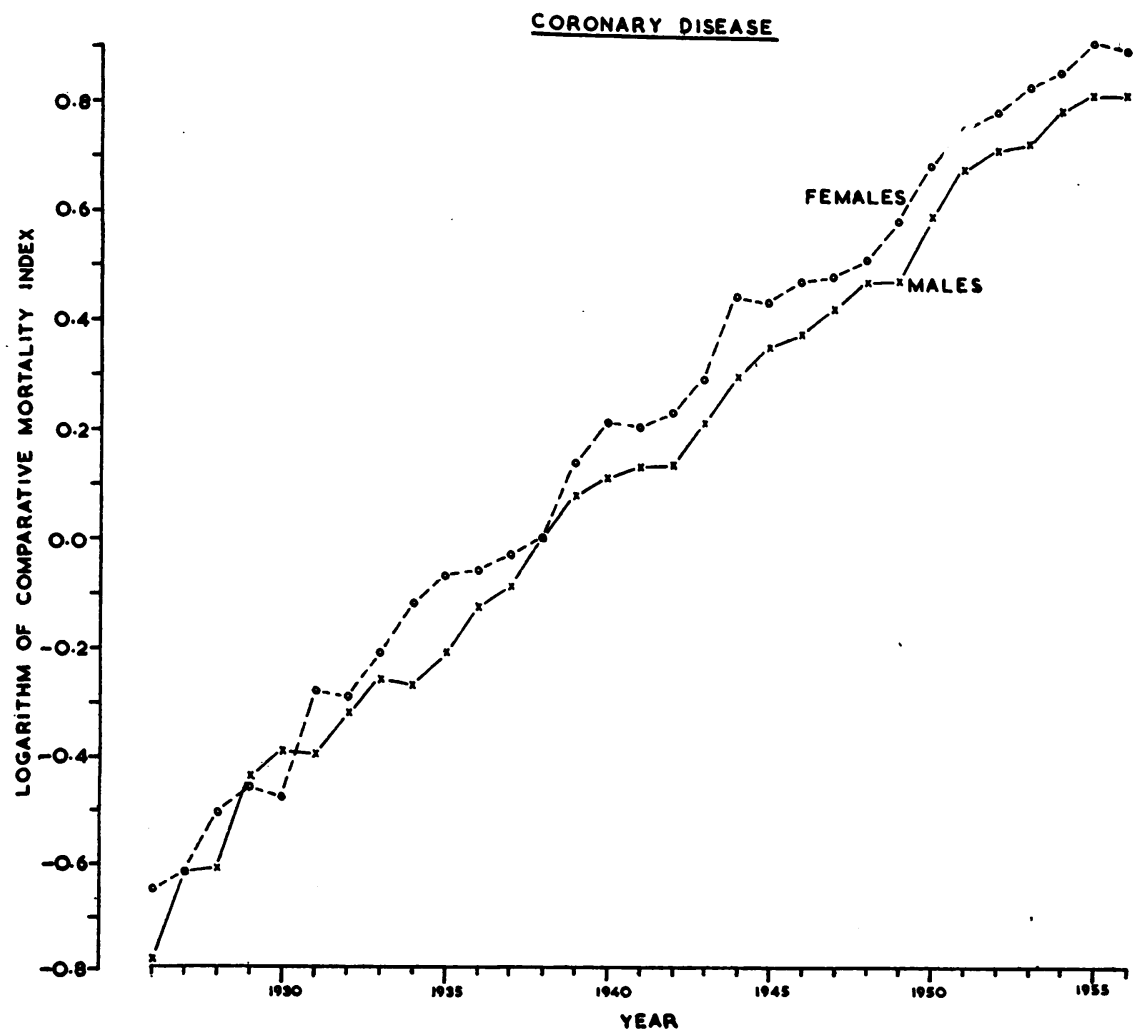

Fio. 2.-Comparative mortality indices for coronary artery disease plotted against a logarithmic scale. 
ratio reaches the level of three to one in the younger age groups and decreases to about three to two for persons aged over 70. The "peak" ratio also moves forward steadily, so that it occurs earlier in life as the overall death rate rises. It will be shown below that similar secular patterns have occurred in England and Wales and in Scotland.

Ggographical Distribution in the Republic of IRELAND.-The death rates for the period 1951 to 1955, standardized against the population in 1951, for the counties and county boroughs in the Republic are shown in Table IV (see also Fig. 3), and in Figs 4 and 5 (opposite).

TABLE IV

AVERAGE ANNUAL MORTALITY RATES PER 100,000 (AT AGE 35+) FOR COUNTIES AND BOROUGHS FOR 1951-1955 BY SEX

\begin{tabular}{|c|c|c|c|c|c|c|c|}
\hline \multirow{2}{*}{$\begin{array}{l}\text { Disease } \\
\text { Sex ... }\end{array}$} & \multirow{2}{*}{$\frac{\cdots}{\cdots}$} & \multirow{2}{*}{$\frac{\cdots}{\cdots}$} & \multirow{2}{*}{$\cdots$} & \multicolumn{2}{|c|}{ Coronary } & \multicolumn{2}{|c|}{ Myocardial } \\
\hline & & & & Male & $\begin{array}{c}\text { Fe- } \\
\text { male }\end{array}$ & Male & $\begin{array}{l}\text { Fe- } \\
\text { male }\end{array}$ \\
\hline Counties & $\begin{array}{l}\text { 1. Carlow } \\
\text { 2. Cavan } \\
\text { 3. Clare } \\
\text { 4. Cork } \\
\text { 5. Donegal } \\
\text { 6. Dublin } \\
\text { 7. Galway } \\
\text { 8. Kerry } \\
\text { 9. Kildare } \\
\text { 10. Kilkenny } \\
\text { 11. Laoghis } \\
\text { 12. Leitrim } \\
\text { 13. Limerick } \\
\text { 14. Longford } \\
\text { 15. Louth } \\
\text { 16. Mayo } \\
\text { 17. Meath } \\
\text { 18. Monagha } \\
\text { 19. Offaly } \\
\text { 20. Roscomn } \\
\text { 21. Sligo } \\
\text { 22. Tipperary } \\
\text { 23. Tipperary } \\
\text { 24. Waterfor } \\
\text { 25. Westmea } \\
\text { 26. Wexford } \\
\text { 27. Wicklow }\end{array}$ & 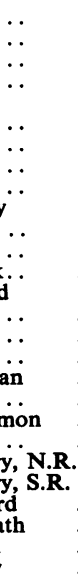 & 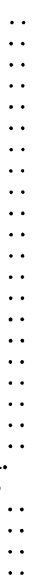 & $\begin{array}{l}254 \\
220 \\
158 \\
262 \\
249 \\
372 \\
243 \\
218 \\
274 \\
324 \\
254 \\
137 \\
193 \\
190 \\
274 \\
180 \\
344 \\
303 \\
271 \\
156 \\
184 \\
294 \\
290 \\
277 \\
276 \\
272 \\
362\end{array}$ & $\begin{array}{r}191 \\
131 \\
76 \\
135 \\
121 \\
168 \\
152 \\
106 \\
148 \\
126 \\
123 \\
43 \\
83 \\
110 \\
121 \\
83 \\
174 \\
128 \\
89 \\
94 \\
76 \\
189 \\
141 \\
159 \\
131 \\
147 \\
164\end{array}$ & $\begin{array}{l}630 \\
379 \\
436 \\
456 \\
323 \\
427 \\
316 \\
331 \\
532 \\
537 \\
535 \\
488 \\
437 \\
630 \\
517 \\
259 \\
547 \\
409 \\
468 \\
549 \\
375 \\
401 \\
548 \\
449 \\
397 \\
504 \\
522\end{array}$ & $\begin{array}{l}546 \\
375 \\
398 \\
494 \\
322 \\
437 \\
389 \\
307 \\
423 \\
467 \\
480 \\
485 \\
419 \\
600 \\
513 \\
223 \\
548 \\
430 \\
444 \\
461 \\
365 \\
331 \\
511 \\
470 \\
384 \\
517 \\
455\end{array}$ \\
\hline Boroughs & $\begin{array}{l}\text { 28. Cork C.E } \\
\text { 29. Dublin C } \\
\text { 30. Dun Lao } \\
\text { 31. Limerick } \\
\text { 32. Waterfor }\end{array}$ & $\begin{array}{l}\text { B. } \\
\text { C.B. } \\
\text { Chaire } \\
\text { C.B. C.B. }\end{array}$ & & $\begin{array}{l}449 \\
453 \\
621 \\
299 \\
270\end{array}$ & $\begin{array}{l}212 \\
213 \\
246 \\
124 \\
124\end{array}$ & $\begin{array}{l}615 \\
427 \\
422 \\
517 \\
742\end{array}$ & $\begin{array}{l}605 \\
454 \\
426 \\
536 \\
742\end{array}$ \\
\hline \multicolumn{2}{|c|}{ Republic of Ireland } & $\ldots$ & .. & 277 & 142 & 433 & 429 \\
\hline
\end{tabular}

In general terms it will be seen that deaths from both types of heart disease are commoner east of the Shannon than west of the Shannon in males and in females. When urban and rural communities are compared, it is apparent that deaths from coronary artery disease are very much commoner in both sexes in the boroughs of Dublin, Cork, and Dun Laoghaire than in any of the counties, and that very much the highest figure is found in Dun Laoghaire. Although the towns of Limerick and Waterford have a death rate from coronary artery disease in males which is similar to that of the counties on the eastern seaboard, the death rate for females in these two towns is lower than in most of the counties and is in the same order as that for women in the midlands and extreme northwest and southwest.

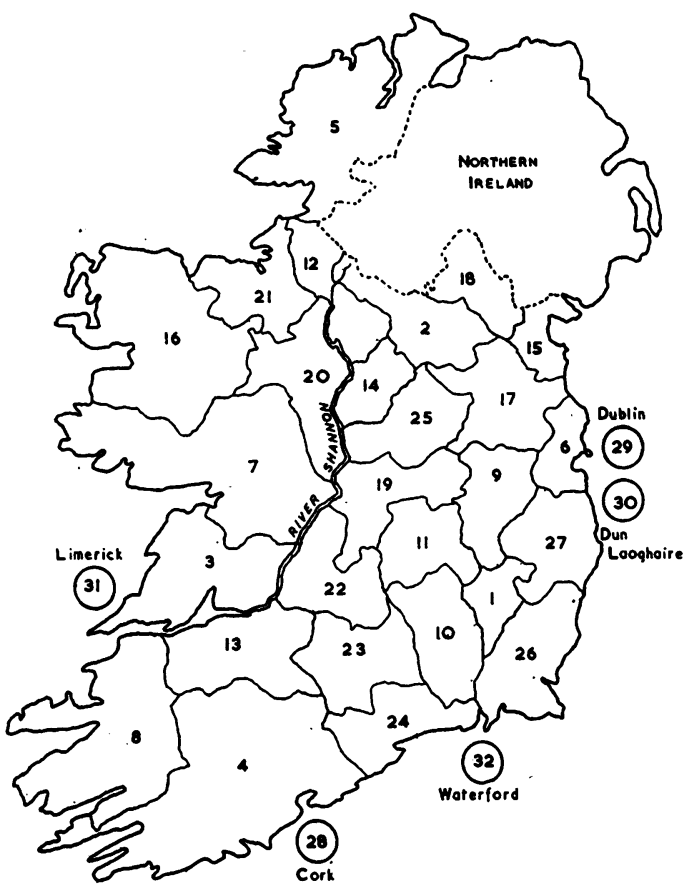

Fig. 3.-Key to counties and boroughs shown in Figs 4 and 5. The numbers refer to the order of listing in Table IV (q.v.).

Death was attributed to myocardial degeneration more often in the five boroughs than elsewhere in the country, but it is worth noting that the figures for both sexes are slightly lower for Dublin city and Dun Laoghaire (which is part of the same conurbation as Dublin city) than for the other three major towns. It is also noteworthy that Dublin county has lower death rates for both sexes than the other counties on the eastern seaboard.

FIG. 4.-Average annual death rates, 1951-1955, for coronary artery disease by counties and boroughs (see also Table IV). The scheme used for shading is the same for both sexes in respect of each disease, but different schemes have been used in this and the following Figure.

FIG. 5.-Average annual death rates, 1951-55, for myocardial degeneration by counties and boroughs (see also Table IV). 


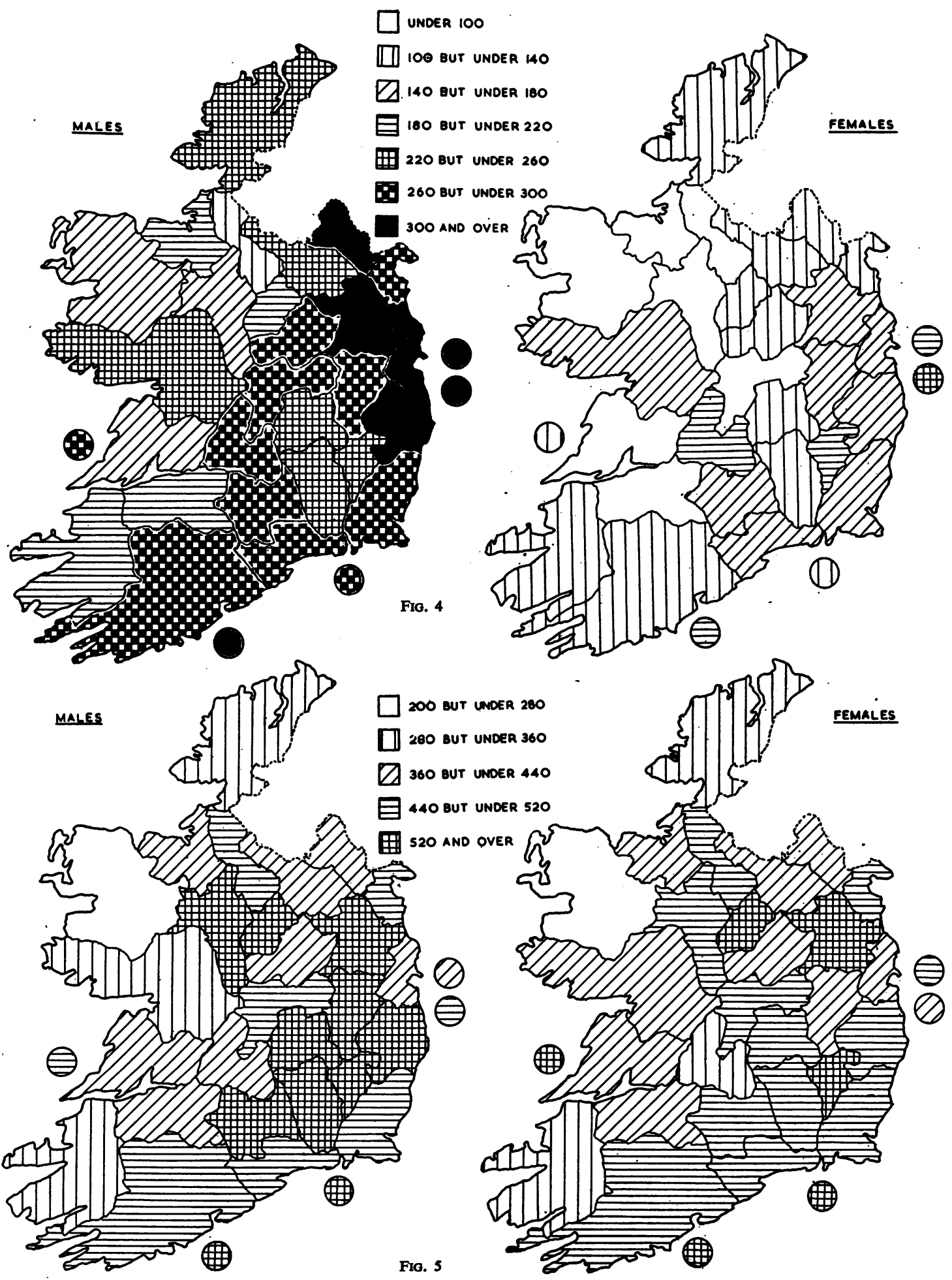

Fio. 5 
OCCUPATION AND INCOME.-Although it has been common practice to collect occupational data at a Census of Population, no analyses are published of causes of death by trade or occupation, so that it is impossible at present to determine the occupational incidence of mortality in the Republic.

Coronary Heart Disease in Relation to Other Causes of DEATH.-Table $V$ shows the secular trend for deaths due to coronary artery disease as a ratio of all deaths for the various age groups. In men of all ages its importance as a cause of death, as compared with all other causes of death, has increased about eleven-fold during the 30 years under review, and it would seem that, with the exception of men in early middle age in whom the index is highest, this risk is borne equally by all age groups. When a similar comparison is made between the second two decades, however, the highest index is found in the oldest age groups, but the indices for early middle age are again higher than those for late middle age. In women also, early middle age is a time when the importance of coronary disease has increased considerably as a cause of death over the entire 30-year period; but in women, the greatest overall increase of coronary disease as a certified cause of death has occurred in those aged 65 and over, with the peak change in the oldest age groups. Comparison between the decade 1936-1945 and 1946-1955 in women shows much less contrast between the age groups. It is worth pointing out that the indices in Table $\mathrm{V}$ reflect the decreasing number of deaths from such causes as puerperal sepsis, lobar pneumonia, and tuberculosis as well as the increasing number of deaths ascribed to coronary artery disease.

COMPARISON OF MORTALITY FROM CORONARY ARTERY DISEASE IN THE REPUBLIC OF IRELAND WITH THAT IN OTHER Countries. - Table VI shows male and female death rates for various countries in 1954, published by the World Health Organization (1956) and standardized against the population of Ireland in 1951. To these the figures for Ireland during 1954 have been added, and all the countries have been ranked in order of the male death rates. It is interesting that, despite the steady increase in the number of deaths ascribed to this cause, the Republic of Ireland is well down the list; moreover, if the ranking had been made by female deaths, its position would have been even lower.

\section{TABLE VI}

DEATH RATES PER 100,000 FOR CORONARY ARTERY DISEASE (AT AGE 40+) FOR VARIOUS COUNTRIES IN 1954, STANDARDIZED TO THE IRISH POPULATION IN 1951

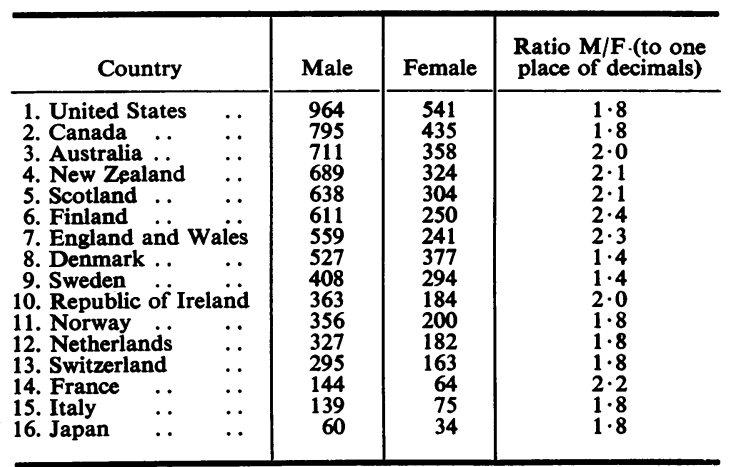

TABLE V

AVERAGE ANNUAL DEATHS FROM CORONARY ARTERY DISEASE PER 1,000 DEATHS FROM ALL CAUSES, BY AGE GROUP AND SEX

\begin{tabular}{|c|c|c|c|c|c|c|c|c|c|}
\hline & \multirow[t]{2}{*}{ Sex } & & \multirow{2}{*}{$\begin{array}{c}\text { Age Group } \\
\text { (yrs) }\end{array}$} & \multicolumn{3}{|c|}{ Average Annual Death Rate } & \multicolumn{2}{|c|}{ Indices taking $1926-35$ as Unity } & \multirow{2}{*}{$\begin{array}{c}\begin{array}{c}\text { Index taking } 1936-45 \\
\text { as Unity }\end{array} \\
1946-55\end{array}$} \\
\hline & & & & $1926-35$ & $1936-45$ & $1946-55$ & $1936-45$ & . 1946-55 & \\
\hline Male & $\cdots$ & - & $\begin{array}{c}35- \\
45- \\
50- \\
55- \\
60- \\
65- \\
70- \\
75- \\
80 \text { and Over }\end{array}$ & $\begin{array}{r}4 \\
10 \\
10 \\
12 \\
11 \\
11 \\
7 \\
4 \\
2\end{array}$ & $\begin{array}{r}19 \\
31 \\
41 \\
43 \\
40 \\
33 \\
21 \\
14 \\
5\end{array}$ & $\begin{array}{r}65 \\
109 \\
126 \\
136 \\
120 \\
110 \\
84 \\
50 \\
20\end{array}$ & $\begin{array}{l}4 \cdot 2 \\
3 \cdot 2 \\
4 \cdot 2 \\
3 \cdot 5 \\
3 \cdot 5 \\
2 \cdot 5 \\
3 \cdot 1 \\
3 \cdot 1 \\
3 \cdot 3\end{array}$ & $\begin{array}{r}14 \cdot 5 \\
11 \cdot 2 \\
12 \cdot 7 \\
11 \cdot 1 \\
10 \cdot 5 \\
9 \cdot 7 \\
12 \cdot 4 \\
11 \cdot 4 \\
12 \cdot 5\end{array}$ & $\begin{array}{l}3 \cdot 4 \\
3 \cdot 5 \\
3 \cdot 0 \\
3 \cdot 2 \\
3 \cdot 0 \\
3 \cdot 3 \\
4 \cdot 0 \\
3 \cdot 7 \\
3 \cdot 8\end{array}$ \\
\hline Female . & . & $\cdots$ & $\begin{array}{c}35- \\
45- \\
50- \\
55- \\
60- \\
65- \\
70- \\
75- \\
80 \text { and Over }\end{array}$ & $\begin{array}{l}2 \\
5 \\
5 \\
6 \\
6 \\
5 \\
4 \\
2 \\
1\end{array}$ & $\begin{array}{r}9 \\
13 \\
17 \\
20 \\
20 \\
21 \\
13 \\
8 \\
5\end{array}$ & $\begin{array}{l}28 \\
38 \\
52 \\
72 \\
74 \\
68 \\
53 \\
33 \\
17\end{array}$ & $\begin{array}{l}4 \cdot 4 \\
2 \cdot 7 \\
3 \cdot 4 \\
3 \cdot 2 \\
3 \cdot 1 \\
4 \cdot 6 \\
3 \cdot 6 \\
3 \cdot 8 \\
5 \cdot 8\end{array}$ & $\begin{array}{r}13 \cdot 9 \\
7 \cdot 7 \\
10 \cdot 7 \\
11 \cdot 7 \\
11 \cdot 4 \\
14 \cdot 6 \\
14 \cdot 8 \\
15 \cdot 5 \\
18 \cdot 3\end{array}$ & $\begin{array}{l}3 \cdot 1 \\
2 \cdot 9 \\
3 \cdot 1 \\
3 \cdot 7 \\
3 \cdot 6 \\
3 \cdot 2 \\
4 \cdot 1 \\
4 \cdot 1 \\
3 \cdot 1\end{array}$ \\
\hline
\end{tabular}


It is notable that, although the Irish rating is very much lower than that of Scotland and of England and Wales, the changes that have taken place during the past $\mathbf{3 0}$ years in Ireland and in Great Britain are similar.
This is illustrated by the data in Tables III and VII and in Fig. 6.

Table VII (overleaf) shows that in England and Wales there was a peak of 5.4 at age 45-49 in 19261935 , and a higher peak of 6.9 at age 35-39 in
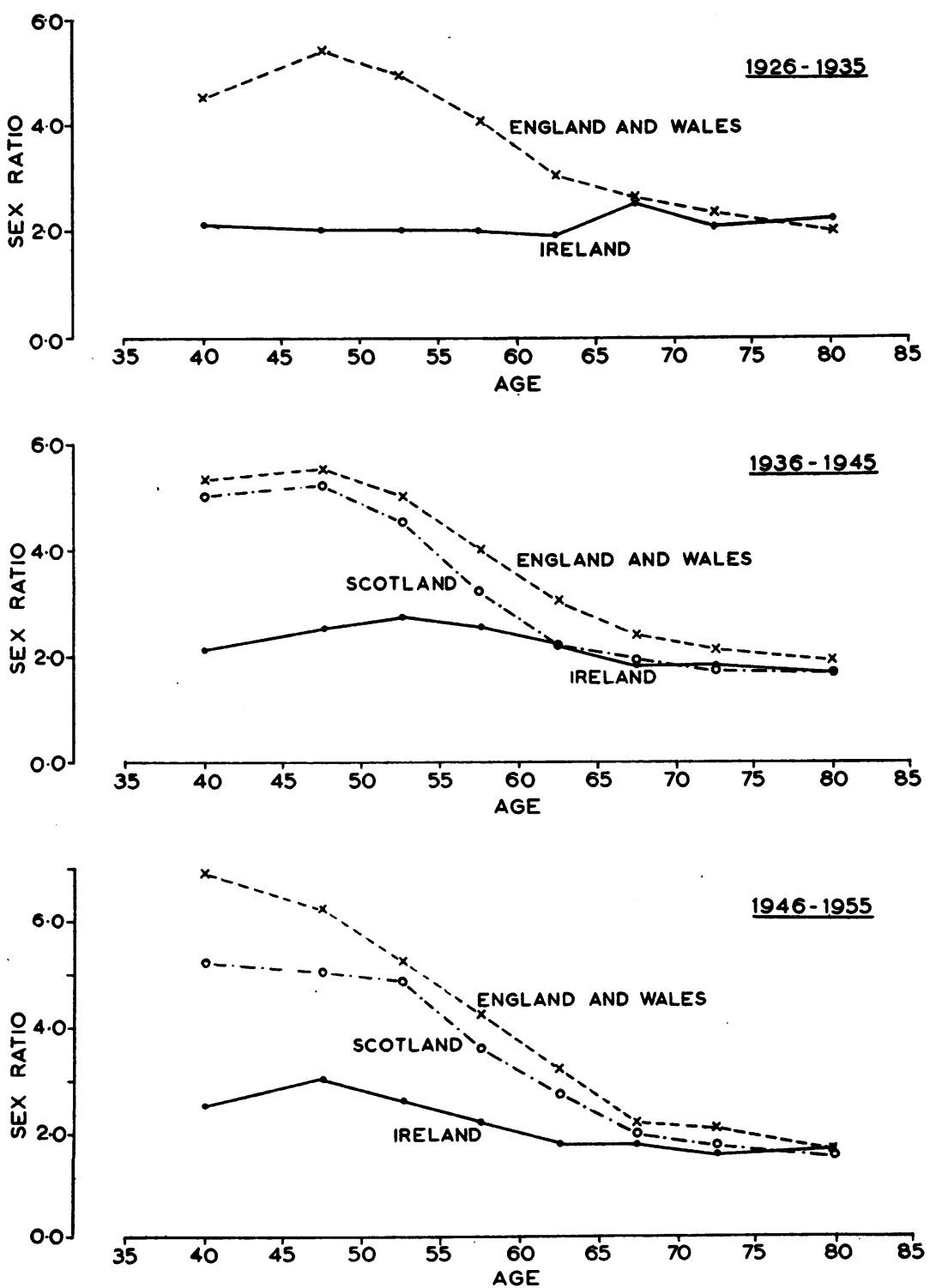

FIG. 6.-Changes in sex ratio of deaths due to coronary artery disease in the British Isles during the past 30 years (see also Table VII). The tendency in each country has been for the peak ratio to occur in an increasingly younger age group. Note that the pattern for Ireland in 1946-1955 is similar to that for Scotland in 1936-1945 and that for England in 1926-35. Note also the similarity between the Irish pattern in 1926-35 and that shown in Fig. 7 for Japan in 1954. 


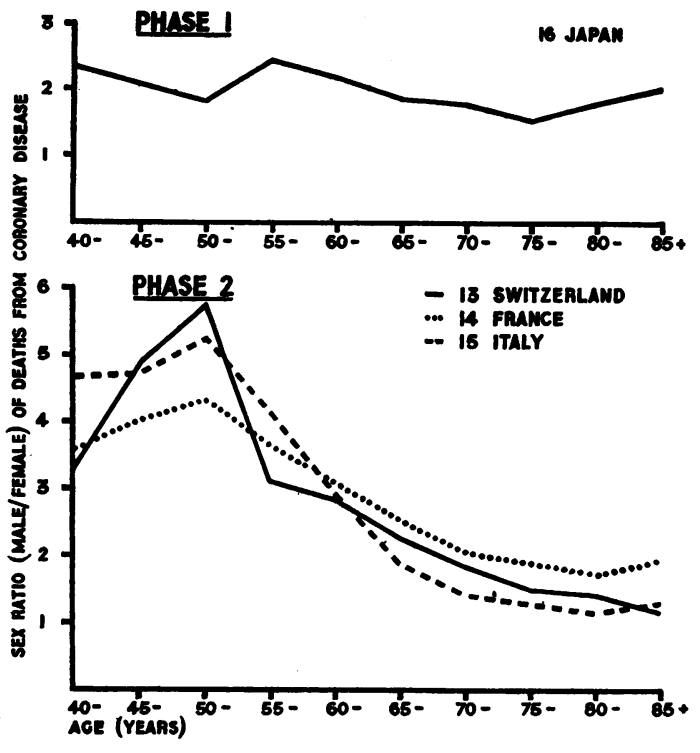

Fig. 7a

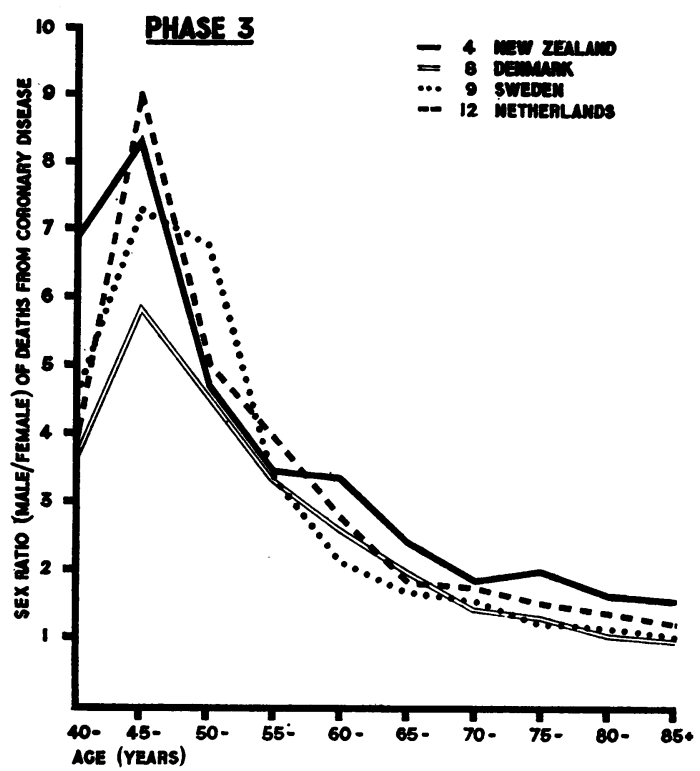

Fig. $7 b$

Fig. 7.- Sex ratios for coronaty artery disease in the countries for which the standardized death rates for 1954 are shown in Table VI; the British Isles have been omitted because a secular treatment of their statistics is shown in Fig. 6 . The number given to each country is that of its ranking by male death rate as shown in Table VI. Note that, with the exception of New Zealand and Norway, the higher the standardized death rate, the younger the age group at which the peak male/female sex ratio appears.

TABLE VII

SEX RATIO (M/F) FOR CORONARY ARTERY DISEASE IN ENGLAND AND WALES AND IN SCOTLAND (FOR IRELAND SEE TABLE III)

\begin{tabular}{c|c|c|c|c|c}
\hline \multirow{2}{*}{$\begin{array}{c}\text { Age } \\
\text { Group } \\
\text { (yrs) }\end{array}$} & \multicolumn{3}{|c|}{ England and Wales } & \multicolumn{2}{c}{ Scotland* } \\
\cline { 2 - 6 } & $1926-35$ & $1936-45$ & $1946-55$ & $1936-45$ & $1946-55$ \\
\hline $35-$ & $4 \cdot 5$ & $5 \cdot 3$ & $6 \cdot 9$ & $5 \cdot 0$ & $5 \cdot 2$ \\
$45-$ & $5 \cdot 4$ & $5 \cdot 5$ & $6 \cdot 2$ & $5 \cdot 2$ & $5 \cdot 0$ \\
$50-$ & $4 \cdot 9$ & $5 \cdot 0$ & $5 \cdot 2$ & $4 \cdot 5$ & $4 \cdot 8$ \\
$55-$ & $4 \cdot 1$ & $4 \cdot 0$ & $4 \cdot 2$ & $3 \cdot 2$ & $3 \cdot 6$ \\
$60-$ & $3 \cdot 0$ & $3 \cdot 0$ & $3 \cdot 2$ & $2 \cdot 2$ & $2 \cdot 7$ \\
$65-$ & $2 \cdot 6$ & $2 \cdot 4$ & $2 \cdot 2$ & 1.9 & $2 \cdot 0$ \\
$70-$ & $2 \cdot 3$ & $2 \cdot 1$ & $2 \cdot 1$ & $1 \cdot 7$ & $1 \cdot 8$ \\
$75+$ & $2 \cdot 0$ & $1 \cdot 9$ & $1 \cdot 7$ & $1 \cdot 7$ & 1.6 \\
\hline
\end{tabular}

* The population in Scotland aged 35-49 showed a considerable decrease between 1921 and 1931 . Presumably this was due to mass emigration during the Depression and followed a normal increase of population in these age groups during the earlier years of the decade. Thus linear interpolation between the two censuses is not a valid method of estimating the age distribution of the population for the interim years. Ratios for the decade 1926-35 have, therefore, been omitted.

1946-1955. The pattern for Scotland is much the same, although the peak ratios are not so high, and in both countries, as in Ireland, the ratios have tended to fall among the oldest sections of the community. Fig. 7 shows the sex ratios for the other countries shown in Table VI; as a rule, it is true to say that the higher the death rate, the younger the age group at which the peak male/female sex ratio occurs. The similarity between the pattern for
Japan in 1954 and for the Republic of Ireland in 1926-1935 is worth noting.

Morris (1956) pointed out that the excess in male deaths due to coronary disease in England and Wales for the age group 45-64 was higher in towns than in rural areas. His figures are given in Table VIII (opposite), which shows a similar comparison in Ireland; Connacht (comprising Counties Galway, Leitrim, Mayo, Roscommon and Sligo) was chosen because it is the most rural portion of the country, but County Galway was omitted because a considerable proportion of its population lives in Galway city, which is the largest town in the Republic not enjoying the status of county or metropolitan borough. Thus, our comparison is rather different from that of Morris, because we contrast the country's "most urban" district with its "most rural" district; it is not altogether surprising therefore that, although we also find a greater male excess in the city, our figures are more extreme than his. Yet it is noteworthy that the incidence of deaths in Dublin and district throughout this age range, is lower for both sexes than in rural England and Wales, particularly since Dublin with its ten general teaching hospitals probably maintains as accurate a standard of death certification as any other district of comparable population. It will also be noted that the figures for rural Ireland are the lowest by a considerable margin of the four areas shown in Table VIII. 


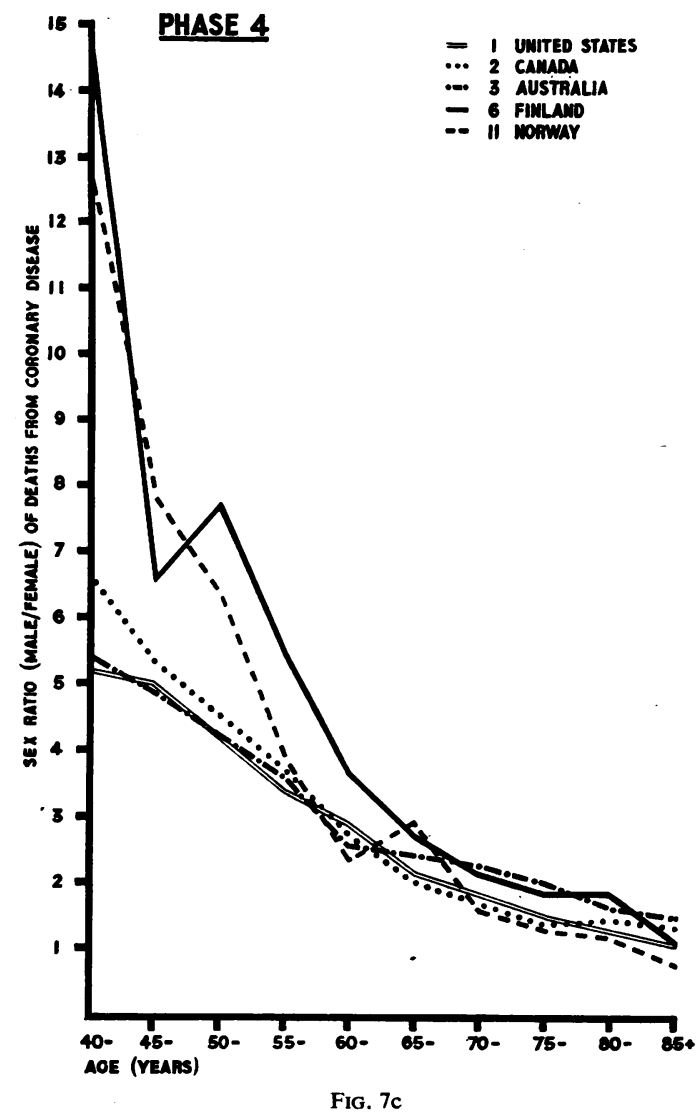

The reliability of death certification in this part of the country is discussed below.

\section{Discussion}

The comparative mortality indices for coronary artery disease show an increase in the 30 years from 1926 to 1956 which is as remarkable for the way in which it has been sustained through the years as for its degree. The question must arise, however, whether this increase reflects a real change in the prevalence of the disease. The registration of deaths as due to coronary artery disease which were previously registered under other headings, or improved methods of diagnosis, could explain the increase and so deserve consideration.

The first possibility is that deaths formerly reported as being due to myocardial degeneration may now be ascribed to coronary artery disease. This, however, is not a reasonable explanation because the crude death rate for myocardial degeneration per 100,000 of the population aged 35 and over in 1926 was 377 and in 1956 it had risen to 388 , whereas during the same period the death rates for coronary artery disease had risen from 6 to 238. Thus, there is an overall rise in deaths due to the two causes, but the major part of this has been ascribed to coronary artery disease. Two points require more careful consideration, however; whereas about 2,700 deaths were ascribed to senility in 1956 , nearly 8,000 were listed as due to this cause in 1926; secondly, over 10,000 of the deaths which occurred in 1926 were not certified by a medical practitioner as compared with just under 3,000 uncertified deaths in 1956. In fact, these two possible sources of error are inter-related, for about 90 per cent. of the uncertified deaths in persons aged 35 and over actually occurred in persons over the age of 65 years, and during the three decades over 60 per cent. of all uncertified deaths were ascribed to senility. Uncertified deaths and deaths from senility occurred but rarely in urban districts, so that the conclusion may be drawn that as medical attendance at the death of old people in rural areas has become increasingly common, fewer and fewer deaths have been registered as due to senility. Thus, many deaths in people aged over 65 years, which would have been recorded as being due to senility in 1926, were attributed to coronary artery disease in 1956. Whether such deaths in 1926 would have been considered as due to angina pectoris by a medical practioner at that time is of course a different question, and one which, though pertinent, must remain unanswered. Nevertheless, it seems probable that the observed increase in deaths

TABLE VIII

MORTALITY FROM CORONARY DISEASE AT AGES 45-64 PER 100,000 FOR URBAN AND RURAL DISTRICTS IN BRITAIN AND IRELAND OVER SPECIFIED PERIODS, BY SEX

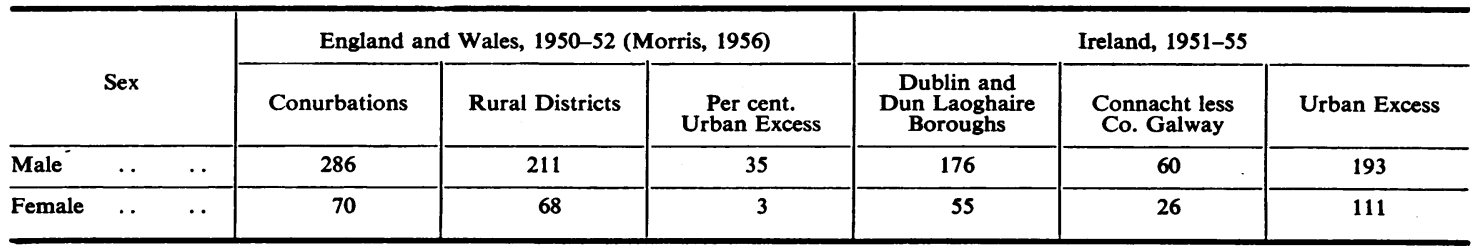


registered as caused by coronary artery disease in the population aged 65 and over is largely due to more precise certification. It has been suggested to us that the death rates in this age group may now be artificially high because it may be "fashionable" to certify a sudden death in an old person as having been caused by coronary artery disease. Whatever the truth of the allegation about fashion, the conclusion is probably incorrect, because there is some evidence to suggest that the morbidity from coronary artery disease in the elderly is very much higher than the death rate reported so far in any age group in the Republic. It has been found that over 20 per cent. of a small sample of old men in Dublin suffer from angina pectoris and that about the same proportion have asymptomatic coronary heart disease (Acheson and Acheson, 1958). These morbidity figures are very similar to those reported for Sheffield by Droller and Pemberton (1953).

In Table II, however, it was shown that the death rates from coronary artery disease have also increased greatly in persons aged 35 to 64 during the past 30 years; this cannot be attributed to any change in the number of times senility has been recorded as a cause of death, because only about one in ten thousand "senile" deaths have been registered in persons under 65. As was stated above, uncertified deaths are not usual in this age group, so that it may be supposed that among them the accuracy of registration has changed but little. It is therefore interesting that it is in this age group that the biggest changes in sex ratio have occurred (See Table III); moreover, similar trends have been observed in Great Britain and elsewhere (see Table VII and Figs 6 and 7). It is, of course, possible that this trend may be partly explained by improved diagnostic methods, for instance, the more widespread use of the electrocardiograph. Be this as it may, it seems improbable to us that such a consistent alteration in the pattern of the sex ratio can be wholly attributed to any cause other than a genuine change in the epidemiology of the disease itself.

The distribution of deaths due to coronary artery disease in Ireland (Fig. 4) is interesting. The incidence of deaths from this cause is higher, as a rule, in urban than in rural areas, and it is also highest in the east and south of the country, both of which Morris (1955) would describe as the most "highly developed" areas. Moreover, the difference between urban and rural areas is very pronounced in the population aged under 64 , in which certification (and probably diagnosis) are more reliable (see Table VIII) as well as in the larger section of the community illustrated in Fig. 4. High development or "westernization" may not, however, be the chief reason for this difference, because anthropological (Hooton and Dupertuis, 1955) and blood group surveys (Hackett, Dawson and Dawson, 1956; Hackett, 1957; Dawson and Hackett, 1958) have shown that in these areas the racial and genetic make-up of the community differs from those found in the areas west of the Shannon. It is possible, therefore, that differences in race as well as in modus vivendi contribute to the sharp contrast seen between Connacht and Dublin (Table VIII). A final conclusion cannot be drawn from the present evidence, but two factors indicate that environment is the more important influence.

First, whereas the incidence of deaths due to coronary artery disease in the boroughs of Cork, Dublin, and Dun Laoghaire is very much higher than in the surrounding countryside (See Table IV), no such distinction exists in respect of the distribution of blood groups, which show a gradual gradient across the island, regardless of urban or rural districts (Hackett, 1957; Dawson and Hackett, 1958). Secondly, although the anthropological characteristics and blood group gene frequencies of the Aran islanders resemble those of eastern Ireland and England, rather than those of the neighbouring mainland (Hooton and Dupertuis, 1956; Hackett and Folan, 1958), their methods and standard of living have changed little over hundreds of years. Only one death on the Aran Islands, however, was certified under group 420 between 1951 and 1955 (a male aged 68), and three (two males and one female) under group 422 for the same period;* expected deaths in the population at risk, based upon rates reported for the neighbouring part of the mainland $\dagger$ during the same period, are four in 420 and six in $\mathbf{4 2 2}$ for males, and two in $\mathbf{4 2 0}$ and four in 422 for females. The population at risk is, of course, very small, and these comparisons should be treated with reserve, but the number of deaths reported on the islands is, in fact, much lower than the "expected" figures for both sexes and both notification groups.

\section{SUMMARY}

(1) Comparative mortality indices show that, for every death in a man or a woman in the Republic of Ireland certified as due to angina pectoris in 1926, over thirty deaths were certified as being due to angina pectoris or coronary artery disease in 1956.

*A doctor is permanently resident on the islands, so that all illnesses are attended and all deaths certified.

tThe comparison has been made with the statistics for the population aged 35 and over in Mayo, a neighbouring county with no large town. 
(2) The secular rate of increase in the male and female death rates has been approximately equal and uniform.

(3) Comparative mortality indices for the group of diseases which are now classed as myocardial degeneration show little change for the period 19261956 for either sex.

(4) The groups of the population which have borne the brunt of the secular increase in deaths certified as due to coronary artery disease are men in early middle age and old age, and women in old age.

(5) Coronary artery disease is more frequently certified as a cause of death in the boroughs of Cork, Dublin, and Dun Laoghaire than in any rural area; the incidence of deaths attributed to this cause is much higher in rural areas to the east of the Republic than those to the west.

(6) The importance of coronary artery disease as a certified cause of death as compared with all other causes of death has increased greatly in the past $\mathbf{3 0}$ years; again, in men the greatest increase is in early middle age and old age, and in women in the older age groups.

(7) The death rate due to coronary artery disease in the Republic of Ireland in 1954 was lower than that in many of the countries whose statistics for that year have been published by the World Health Organization; the average mortality rates for both sexes aged 45-64 in Dublin City and Dun Laoghaire from 1951-1955 were much lower than those in rural or urban areas of England and Wales in 1950 1952.

(8) As the incidence of deaths due to coronary artery disease has increased, so the male/female sex ratio in the various age groups has changed, and the greatest changes have been among the younger age groups in whom certification is likely to be less erroneous. It is suggested that the relationship observed in the Republic between overall incidence of deaths due to coronary artery disease and the sex ratio for the various age groups may be a universal phenomenon.

(9) Reasons are given why the increase in deaths reported as due to coronary artery disease in the Republic of Ireland is considered to be a genuine reflection of a change in the prevalence of the disease in the younger section of the community at risk. Improved diagnosis and certification have almost certainly contributed to the increase in registered death rates from this cause in old age.

We are deeply grateful to Dr. M. D. MacCarthy and Mr. J. F. Knaggs of the Central Statistics Office, Dublin, for making available to us a considerable amount of unpublished data.

Professor W. J. E. Jessop and Mr. David Hewitt have kindly criticized the text.

\section{REFERENCES}

Acheson, R. M., and Acheson, E. D. (1958). (In the press).

Dawson, G. W., and Hackett, W. E. R. (1958). Ann. hum. Genet., 22,

Department of Health, Ireland (1955 and 1957). "Reports on Vital Statistics for Years 1953 and 1954". C.S.O., Dublin. (Eire-An Statistics for Yoinn Sláinte).
Roint

Roinn Sláinte). Annual Reports of the Registrar General for Years 1945-1952". C.S.O., Dublin.

Department of Local Government and Public Health, Ireland (19271945). "Annual Reports of the Registrar General for Years 19261944", C.S.O. Dublin.

Droller, H., and Pemberton, J. (1953). Brit. Heart J., 15, 199.

General Register Office, Edinburgh (1923). "Census of Scotland, 1921, vol. 1". H.M.S.O., Edinburgh.

Hackett, W. E. R. (1957). Address read before the British Association (Section H) in Dublin (for brief extract see Brit, med. $J, 1957,2,698$ ) , Dawson, G. W. P., and Dawson, C. J. (1956). Heredity, 10, 69. -, and Folan, M. E. (1958). Irish J. med. Sci., series 6 (In the press).

Hooton, E. A., and Dupertuis, C. W. (1955). "Anthropological Survey of Ireland, Part I". Peabody Press, Harvard University.

Morris, J. N. (1951). Lancet, 1, 1, 69.

- (1955). Med. Offr., 94, 251.

- (1956). Brit. J. industr. Med., 13, 287. , and Heady, J. A. (1953). Ibid., 10, 245. , and Barley, R. G. (1952). Brit. med. J., 1, 503.

, Raffe, P. A. B., Roherts, C. G., and Parks, J. W. (1953). Lancet, 2, 1053, 1111.

Registrar General for England and Wales (1928-1957)). "Statistical Review for Years 1926-1955". Tables-Part I, Medical. H.M.S.O., London.

- (1953b). "Statistical Review for England and Wales for the Two Years 1948 and 1949". Text-Medical. H.M.S.O., London. for Scotland (1938-1957). "Annual Reports for Scotland for Years 1936 (No. 82) to 1955 (No. 101)". H.M.S.O., Edinburgh.

Ryle, J. A., and Russell, W. T. (1949). Brit. Heart J., 11, 370.

World Health Organization (1956). Epidem. vital Statist. Rep., 9, 582. 